\section{Environmental Responsibility, Psychological Distance, and Environmental Consumption: Mediation in Accounting Students}

\author{
Responsabilidade Ambiental, Distância Psicológica e Consumo Ambiental: \\ Mediação em Estudantes de Contabilidade
}

\author{
Alison Martins Meurer ${ }^{1} \odot$ \\ Cristina Viana de Jesus ${ }^{10}$ \\ Luiz Panhoca ${ }^{1}$ [0
}

\section{ABSTRACT}

Objective: this study aimed at analyzing the relationship between psychological distance and environmental consumption, embodied in the intention to purchase and loyalty to pro-environmental products, mediated by environmental responsibility. Methods: 113 responses obtained through a survey conducted with academics from the Accounting Sciences course were analyzed, using the structural equation modeling technique to identify the proposed relationships and the possible mediating effect between the constructs. Results: the results illustrate the existence of partial mediation of environmental responsibility in the relationship between psychological distance and the intensity of purchase and total with the loyalty of consumers. The non-rejection of the research hypothesis exposes the importance of analyzing psychological elements regarding to the consumption behavior of pro-environmental products. Conclusions: theoretical contributions indicate that environmental responsibility is capable of promoting the consumption of pro-environmental products. In practical terms, Accounting courses can incorporate discussions about socio-ethical-environmental values, expanding classroom debates about environmental responsibility beyond the financial aspects specifically aimed at creating economic value for the organization.

Keywords: psychological distance; environmental responsibility; accounting sciences.

1. Universidade Federal do Paraná, Programa de Pós-Graduação em Contabilidade, Brazil.

Cite as: Meurer, A. M., Jesus, C. V. de, \& Panhoca, L. (2021). Environmental responsibility, psychological distance, and environmental consumption: Mediation in accounting students. Revista de Administração Contemporânea, 25(4), e190223. https://doi.org/10.1590/1982-7849rac2021 190223.en

\section{RESUMO}

Objetivo: este estudo teve como objetivo analisar a relação entre a distância psicológica com o consumo ambiental, consubstanciado na intenção de compra e na lealdade a produtos pró-ambientais, mediadas pela responsabilidade ambiental. Métodos: foram analisadas 113 respostas obtidas por meio de uma survey realizada junto aos acadêmicos do curso de Ciências Contábeis utilizando-se da técnica de modelagem de equaçôes estruturais para identificar as relações propostas e o possível efeito mediador existente entre os construtos. Resultados: os resultados ilustram a existência de mediaçáo parcial da responsabilidade ambiental na relaçáo entre distância psicológica com a intensidade de compra e total com a lealdade dos consumidores. A não rejeição da hipótese de pesquisa expóe a importância da análise de elementos psicológicos frente ao comportamento de consumo de produtos pró-ambientais. Conclusóes: as contribuiçóes teóricas indicam que a responsabilidade ambiental é capaz de promover o consumo de produtos pró-ambientais. Em termos práticos, cursos de Ciências Contábeis podem incorporar discussôes sobre valores éticos socioambientais, expandindo os debates em sala de aula sobre responsabilidade ambiental para além dos aspectos financeiros voltados especificamente para a criação de valor econômico para a organização.

Palavras-chave: distância psicológica; responsabilidade ambiental; ciências contábeis.
JEL Code: M4, J13, P46. Editor-in-chief: Wesley Mendes-Da-Silva (Fundação Getulio Vargas, EAESP, Brazil) (]) Reviewers: André G. C. Machado (Universidade Federal da Paraiba, CCSA, Brazil) (]) One of the reviewers chose not to disclose his/her identity Peer Review Report: The Peer Review Report is available at this external URL. Received: June 10, 2019 Last version received: June 03,2020 Accepted: June 03, 2020

\begin{tabular}{|c|c|c|c|c|c|c|c|c|c|}
\hline & 1 & 2 & 3 & 4 & 5 & 6 & 7 & 8 & 9 \\
\hline $1^{\text {st }}$ round & x & $x$ & $\stackrel{9}{2}$ & (x) & $x$ & $x$ & (x) & $\stackrel{9}{2}$ & \\
\hline $2^{\text {nd }}$ round & (x) & $\stackrel{0}{2}$ & & & & & & & \\
\hline $3^{\text {rd }}$ round & $\stackrel{9}{2}$ & & & & & & & & \\
\hline $4^{\text {th }}$ round & $\stackrel{0}{2}$ & & & & & & & & \\
\hline $5^{\text {th }}$ round & $\stackrel{0}{2}$ & & & & & & & & \\
\hline
\end{tabular}




\section{INTRODUCTION}

There are several reasons that point to the devastating effects of business and human actions resulting from the environment exploration, which has awakened in society an incentive to adhere to ethical environmental consumption imposing demands on organizations to improve their strategies and environmental protection schemes, based on socially responsible, legitimate conduct, and harmonious interaction with the environment (Kautish \& Sharma, 2019; Shafiei \& Maleksaeidi, 2020).

In this context, it is noted that companies have been adjusting the offer of products and services for an ecologically correct positioning (Global Industry Analysts, 2013). Governments have also increased the number and scope of environmental regulations (United States of America, 2015). These concerns arise from the maximization of the consumption power that has fostered industrial growth and presented itself as an aggravating element from the threats of degradation to the environment and climate change (Ariztía et al., 2014). Thus, debates about this theme and conscious consumption have permeated social and political agendas more intensely, promoting changes in environmental legislation and in the consumption of pro-environmental brands and products (Ariztía et al., 2014; Chen, 2011).

Specifically in the sphere of consumption, part of consumers have positive impressions and sympathies with pro-environmental products, but their intentions and purchasing habits remain linked to the traditional perception that consists of practices that do not observe environmental aspects arising from the services or products purchased (White, MacDonnell, \& Ellard, 2012). The cost and benefit dynamics have been identified as one of the main barriers to entering this consumer niche since the financial disbursement, time, and physical or mental effort linked to pro-environmental products can discourage people from modifying their consumption practices (Gordon-Wilson \& Modi, 2015).

The change from traditional consumption practices to an environmentally responsible attitude leads to efforts and social changes, based on educational actions adapted to the culture of each social group (Sacchi, Riva, \& Aceto, 2016; Yu, Yu, \& Chao, 2017). Brügger, Morton and Dessai (2016) argue that resistance to the adoption of environmentally responsible and ethical consumption habits lies in the feeling that environmental changes are distant, in remote times and places, and that they do not directly impact the lives of individuals.

This impression of detachment characterizes psychological distance, which indicates that an object or phenomenon perceived close to the self tends to be dealt with in a concrete way and arouses more intense concerns, while distant objects or phenomena are seen as something abstract (Trivedi, Patel, \& Acharya, 2018). Thus, if environmental changes were seen as close and concrete, consumer behavior would be more prone to ethical consumption practices (McDonald, Chai, \& Newell, 2015). In this way, the distant perception of environmental consequences is one of the main barriers for awareness, as environmental effects and indicators require comparison between observation points over the years on an environmental, geographical, and temporal macro-micro scale (Lecours et al., 2015; Trenberth, 2012).

Another point of view defended by entities such as the Institute of Medicine (Institute of Medicine (US), Roundtable on Environmental Health Sciences, Research, and Medicine, 2007) and researchers like Vitell (2015) asserts that people's environmental responsibility is related to ethics and social responsibility, which can be associated to standards and moral principles linked to purchases, use, and disposal of goods and services. In this approach, the practice of ethical consumption is seen as a moral judgment (Gilead, Liberman, \& Maril, 2014) carried out daily and that observes the individual consequences, the ethical posture, and the collective actions aligned with self and socially responsible standards (Vitell, 2015; Yu et al., 2017). This perspective argues that promoting environmental responsibility is one of the most effective ways to promote environmental consumption.

Regarding Brazilian consumers, the annual survey of conscious consumption analysis carried out by the National Confederation of Shopkeepers (CNDL) and by the Credit Protection Service (Serviço de Proteção ao Crédito [SPC], 2019) showed that in 2019 about 97\% of the interviewees had difficulties in adopting consumer practices of conscious and environmentally responsible consumption. The 2019 Conscious Consumption Indicator (CCI) was $73.30 \%$, representing a consumption profile in transition to a responsible socio-environmental posture.

The CCI is calculated based on consumer behavior, being divided into three sub-indicators, respectively called financial practices, environmental practices, and practices of engagement and social responsibility. The results of the study highlight the fact that the youngest have the lowest percentages of conscious and responsible behavior in all sub-indicators.

As in most countries considered emerging, the youngest represent a large portion of the population. In 2018, about $42.90 \%$ of Brazilians were under 30 
years old (Instituto Brasileiro de Geografia e Estatística [IBGE], 2020). This population group represents the workforce and the present and future consumer market, with a high share of contribution to ensuring the survival of the planet (Mohiuddin, Al Mamun, Syed, Masud, \& $\mathrm{Su}, 2018)$.

In this sense, different studies have been conducted with younger age groups in order to understand their consumption behavior to outline actions that foster environmental awareness and responsibility (e.g., Shafiei \& Maleksaeidi, 2020; Yu et al., 2017). In particular, university students have been prominent in these researches, as there is evidence in the literature that indicates that behaviors shaped in the university context tend to be manifested in the work environment and in other social contexts (Meriac, 2012). Thus, higher education is perceived as a solid platform, capable of encouraging and guiding individuals to adopt proenvironmental behaviors (Khan, Fatima, \& Bose, 2019).

Some researches have specifically observed students belonging to courses in the business area, arguing that these future professionals will be responsible for the production, distribution, and consumption of proenvironmental products, as well as for the promotion of sustainability and corporate social responsibility (Khan et al., 2019; Mohiuddin et al., 2018). As an example, there is the Accounting Sciences course, the focus of this research, which is under the scope of the business area and has received strong criticism in recent decades for not sharing among its academics and professionals attitudes aligned with ethical social life, sometimes exceeding the limits of moral integrity (Kelly \& Alam, 2009; McCabe, Butterfield, \& Treviño, 2006).

Kelly and Alam (2009) recognize the need to observe the behavior and training of Accounting academics in the face of environmental issues and raise concerns about how environmental and sustainable education has been anchored under the focus of creating economic value, to the detriment of promotion of social and ethical environmental values. It is believed that this strictly economic approach that guides Accounting Sciences courses can distance academics from pro-environmental behaviors, with environmental responsibility being a counterweight to this relationship.

Therefore, the approach of psychological distance, environmental responsibility, and environmental consumption in future accountants is important to understand how this organizational actor, responsible for generating information and capable of interfering in social responsibility and corporate sustainability, guides his consumption posture in private life. Thus, it is argued that the technical character of the Accounting Sciences course needs to provide opportunities for discussion and the search for spaces that are also responsible for the social sphere, as Accounting derives from human interaction.

In this sense, it is perceived that there is an evolutionary scenario that induces to advance the discussions regarding the theme, encouraging the joint investigation of these perspectives based on the relationship of ethical and psychological elements in the face of environmental consumption, seeking to understand: What is the relationship between psychological distance and environmental consumption mediated by the environmental responsibility of students in the Bachelor of Accounting course? Therefore, the aim of the study is to analyze the relationship between psychological distance and environmental consumption mediated by the environmental responsibility of students in the Bachelor of Accounting Sciences course. In this investigation, the term 'environmental consumption' is understood as the intention to purchase and loyalty to pro-environmental products.

The research presents three main contributions. First, the individual's propensity to adhere to the consumption of pro-environmental products has been addressed in the literature based on socioeconomic variables, aiming at identifying the motivators of this adherence through the analysis of gender, age group, social class, level of education, among other objective characteristics. Eckhardt, Belk and Devinney (2010), Ferraz, Romero, Rebouças and Costa (2016) and Shafiei and Maleksaeidi (2020) are examples of studies focused on this approach.

This research contributes and advances in relation to the theme, as it bases its discussions on different subjective elements, such as the dimensions of environmental responsibility, indicating that the strategies of engagement of new consumers to pro-environmental products are affected by psychological responses and perception of the individual with respect to environmental changes. These insights are delimited in this study to young university students from a course belonging to the business area, which compose the research sample.

The second concerns the joint study of purchase intent and loyalty to pro-environmental products. Most previous studies have observed these elements in a dichotomous way, without exploring previous variables that can affect purchase intent and loyalty to proenvironmental products simultaneously. The research's third and main contribution consists of processing information and identifying behavioral patterns of consumption in a sample that ultimately consists of citizens of the future. When proposing reflections on elements linked to the consumption behavior of these 
young students belonging to a course in the business area, educational actions aimed at correcting future behaviors can be proposed.

In addition, the need to understand the purchasing behavior of pro-environmental products is opportune due to environmental, scientific, and communication advances, such as the internet and social media, increased awareness and concern of consumers with environmental issues (Groening, Sarkis, \& Zhu, 2018). These elements characterize a portion of contemporary society that strives to adjust its consumption behavior to ecologically sustainable standards.

The research results contribute to the advancement of the theme as they reinforce the importance of observing psychological elements in view of the purchase intention and consumer loyalty to pro-environmental products, since psychological distance and environmental responsibility were predictors and intermediaries of this pro-environmental stance. Educational actions supported by the reduction of psychological distance can be implemented in order to promote environmental responsibility, purchase intent, and loyalty to proenvironmental products.

The next section of this study presents the theoretical foundation and the background that supports the hypothesis of this research. Then, the methodological elements, the results, the final observations, and the main implications of the research are described.

\section{THEORETICAL FOUNDATION}

\section{Psychological distance}

The concept of psychological distance is based on the theory of level of interpretation (construal level theory - CLT) that analyzes the individual's perceptions in relation to past or future events and the degree of abstraction - level of interpretation - attributed to the analyzed object. Because it is a theory derived from social psychology, CLT addresses human behavior through the individual's mental interpretations and the proximity or distance that are related to the events analyzed (Trope \& Liberman, 2010).

Trope and Liberman (2010) state that situations not perceived in the present are created mentally by people through mental interpretations. The levels of interpretations referring to the degree of abstraction attributed to the facts are different among individuals, since the degree of abstraction originates through personal perceptions (McDonald et al., 2015). Thus, facts belonging to other spatial, temporal, social, or hypothetical dimensions tend to be mentally constructed and perceived as abstract and distant (Brügger et al., 2016; Trope \& Liberman, 2010).

Conceptually, the spatial dimension is related to local aspects, of how much something can happen near or far from the individual. Temporal refers to time, if for a certain fact it is believed that the occurrence will occur in the near or distant future. Social distance is linked to the perception of proximity to events and their effects inherent to the individual and close people or distant social groups. Finally, the hypothetical dimension refers to the degree of uncertainty about the occurrence of a certain event (Trope \& Liberman, 2010). Therefore, for McDonald, Chai and Newell (2015), "dimensions represent the ways in which an object can be distanced from the self in the here and now" and embodied in mental creations (McDonald et al., 2015, p. 110).

Research points out that there are interrelationships between such dimensions of psychological distance. This means that the way in which something is represented in spatial terms can also be related to social, temporal, and/ or hypothetical aspects (McDonald et al., 2015; Spence, Poortinga, \& Pidgeon, 2012; Trope \& Liberman, 2010). Brügger et al. (2016) argue that these representations guide subsequent judgments and decisions shaping the individual's way of acting and thinking.

Regarding environmental aspects, Spence, Poortinga and Pidgeon (2012) state that a portion of the population has a high degree of uncertainty regarding climate change and believes that if it occurs, it will affect distant places in the distant future and with unknown individuals. Therefore, psychological distance in its four dimensions is characterized as one of the main predictors of ethical environmental behavior (McDonald et al., 2015). The low perception of environmental impacts causes the individual's behavior to be directed to traditional consumption practices and not to be involved with proenvironmental policies (Singh, Zwickle, Bruskotter, \& Wilson, 2017), evidencing the importance of this construct in research that aim at verifying consumer behavior and the relationship with the environment.

\section{Environmental responsibility}

The purchase of pro-environmental products is seen as a moral judgment that characterizes the principle of responsibility and commitment to the environment. Environmental responsibility is incorporated into the set of environmental moral principles that characterize environmental ethics, along with two standards of responsibility, the self and the social. The first is derived from altruism and spontaneity related to actions that 
make the subject feel good about himself. The second stems from social pressures for acceptable standards and attitudes of environmental engagement (Joshia \& Rahman, 2015; Yu et al., 2017).

Environmental responsibility has been treated in the literature as a synonym for the construct that characterizes the ethical behavior of the consumer, seen as the values that guide the individual to obtain, use, and dispose of goods and services (Kautish \& Sharma, 2019). In this context, the ethical behavior of consumers has been observed under different approaches. In the economic sphere, the number of organizations that seek to demonstrate a responsible attitude toward the environment and society grows. In the academic context, studies have provided evidence about the reason for the change in society's posture in relation to impacts on the environment, with emphasis on predictors of ethical and pro-environmental behaviors (Afonso, Bornia, Echegaray, \& Andrade, 2016; Ariztía et al., 2014; Chen, 2011; Eckhardt, Belk, \& Devinney, 2010; Fakhrudin, Karyanto, \& Ramli, 2018; Gordon-Wilson \& Modi, 2015; Kautish \& Sharma, 2019; Shafiei \& Maleksaeidi, 2020; Vitell, 2015).

Eckhardt et al. (2010), for example, used qualitative methods and an interpretative approach to analyze consumer behavior in relation to the nonenvironmental products usage. The authors' discussions come from the low proportion of the market occupied by pro-environmental products. The conclusions point out that although there is environmental awareness on the part of consumers, ethical consumption is shaped by the economic situation, political education, and development and working conditions of the countries. The consumption of pro-environmental products is sometimes considered a luxury and causes financial increases that inhibit the expansion of the consumer market.

Afonso, Bornia, Echegaray and Andrade (2016) used the item response theory (IRT) to measure the sustainable behavior of consumers from a sample of 250 adults aged from 18 to 69 years. Using quantitative techniques, the authors identified that sustainable behavior can be divided into steps that follow a script. Priority is given to simple actions that require less financial and time expenditure, to later adopt a more conscious attitude toward consumption, such as the purchase of organic products and the engagement in debates related to the theme.

Kautish and Sharma (2019) analyzed the functional relationships between terminal and instrumental values, environmental awareness, and behavioral intentions for the purchase of ecological products in India. Terminal and instrumental values were shown to be positively related to environmental awareness and to a lesser extent to behavioral intentions. Although the terminal aspects have been shown to be important predictors of environmental awareness and positive behavioral intentions, it is the instrumental values that play a prominent role in the consumption decision.

Thus, it is important that the benefits of consuming pro-environmental products are exposed so that the impacts on the consumer's life can be seen in the short term, since the instrumental value is presented as the main determinant of behavioral intentions.

Shafiei and Maleksaeidi (2020) verified the factors linked to the pro-environmental behavior of 310 Iranian university students. The results indicated that the factors that relate to pro-environmental behavior are positively embodied in self-efficacy, perceived rewards, and environmental attitude. On the other hand, there is a negative relationship with the response costs perceived by the respondents, such as, for example, the feeling of higher financial disbursements in view of the adoption of pro-environmental practices. In addition, variables such as gender, marital status, and residence in an urban or a rural region do not affect pro-environmental behavior, and the course and degree, graduation or post-graduation, are able to direct the attitudes of respondents inherent to ethics environmental.

Thus, the literature has reinforced, through different scientific discoveries, the effects of psychological variables on consumer behavior in relation to proenvironmental products, as the decisions to purchase and use these products involve ethics, social responsibility, and subject's self.

\section{Purchasing intent and consumer loyalty}

The purchase intention is characterized as a conscious plan in which mental judgments are made and targeted people's future behaviors (Fakhrudin et al., 2018; Trivedi et al., 2018). For Ferraz et al. (2016), this variable mediates the relationship between consumer attitudes and behaviors, as it acts "as a kind of index that a person would be willing to try to perform in favor of an action." (Ferraz, Romero, Rebouças, \& Costa, 2016, p. 609). The importance of studying this construct is in the predictive power of consumer behavior and in the analysis of factors that are related to their decisionmaking (Lee, 2017; Yu et al., 2017).

Another element to be observed in the consumer market is the loyalty that characterizes the extent to which an individual is "deeply committed to consuming a product/service consistently, making repeated purchases of the same brand, and neglecting situational influences 
and marketing efforts" (Oliver, 1999, p. 34). According to Yu, Yu and Chao (2017) and Lee (2017), competitiveness and variety of options mean that the purchase intention and consumer loyalty to environmentally ethical products receive more attention from companies. Oliver (1999) points out that loyalty to pro-environmental products is related to the individual's environmental responsibility, enabling the joint verification of its relationship to loyalty and purchase intention.

Ferraz et al. (2016) verified the relationship between attitude, purchase intention, and ecologically conscious buying behavior. Data analysis indicated that there is a relationship between the three variables, with price and perceived quality being the most relevant factors in the transition from purchase intention to effective consumer purchase.

Finally, Yu et al. (2017) analyzed the mediating effect of environmental responsibility on the relationship between psychological distance and environmental consumption. The research was carried out through the participation of Taiwanese university students, using the structural equation modeling technique in the data analysis. There was a positive relationship between environmental responsibility with the intention to purchase and loyalty to environmentally ethical products. In view of the findings, Yu et al. (2017) argue the need to develop consumer self-responsibility in a continuous and broad way in order to encourage consumers to purchase products that are less harmful to the environment.

In order to enrich the findings and discussions regarding the consumption of pro-environmental products, this investigation is guided by the following research hypothesis: 'The relationship between psychological distance with the intention to purchase and loyalty to pro-environmental products is mediated by responsibility environmental.'

Based on the hypothesis listed, Figure 1 illustrates the theoretical model that guides the study.

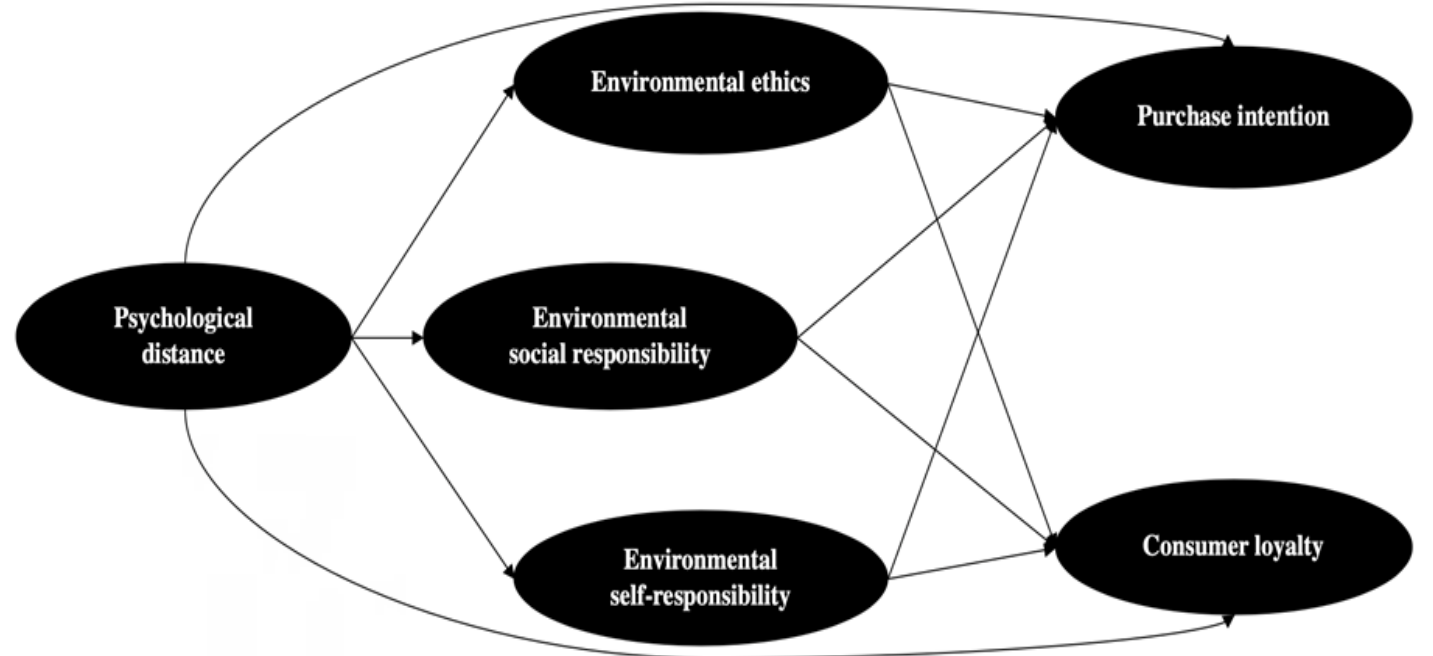

Figure 1. Theoretical research model.

Source: prepared by the authors.

Figure 1 indicates that environmental responsibility, embodied by environmental ethics, environmental social responsibility, and environmental self-responsibility, mediates the relationship between psychological distance and purchase intention and consumer loyalty to pro-environmental products. Such a relationship is verified from the three premises (a), (b), and (c) defended by Baron and Kenny (1986).

Premise (a) considers that variations in the levels of the independent variable (psychological distance) significantly affect variations in the assumed mediator (environmental ethics, environmental social responsibility, and environmental self-responsibility). In premise (b), the variations of the possible mediator (environmental ethics, environmental social responsibility, and environmental self-responsibility) significantly affect the variations of the dependent variable (purchase intention and consumer loyalty).

Finally, premise (c) consists of a decrease or absence of significant direct effects between the independent variable (psychological distance) and the dependent one (purchase intention and consumer loyalty) with the inclusion of the presumed mediating variable (environmental ethics, responsibility social responsibility, and environmental self-responsibility), since if the inclusion of the presumed mediating variable reduces the direct effect to zero, with the 
significant effects of conditions (a) and (b) remaining, it is possible to affirm the existence of total mediation; in case this reduction does not goes to zero, then there is partial mediation.

\section{METHODOLOGICAL PROCEDURES}

This research has a descriptive character and a quantitative approach since the data were collected through a survey carried out with academics from the Bachelor of Accounting Sciences course at a public university in southern Brazil. The study population is non-probabilistic, defined by accessibility, and consists of 211 students, 143 of whom participated in the research and 113 responses were considered valid to be analyzed because they were answered in full.
Respondents completed a questionnaire divided into two blocks. The first consisted of the instrument adapted from Yu et al. (2017), in which there were questions regarding consumer behavior in relation to pro-environmental products. A numerical scale of intensity of agreement was used with labels on the numerators of the extremities, $1=$ I do not agree and $7=$ I totally agree. The numerical scales allow the quantitative analyzes usage, since their values do not fulfill a strictly semantic and categorical role as the Likert scale. The first and fourth constructs were the only ones with four statements each, the rest being composed of five statements each. Thus, the first block of the data collection instrument was composed of 28 statements, as shown in Annex I. Table 1 presents the research constructs, description, and exemplification of the statements of the data collection instrument.

Table 1. Research constructs.

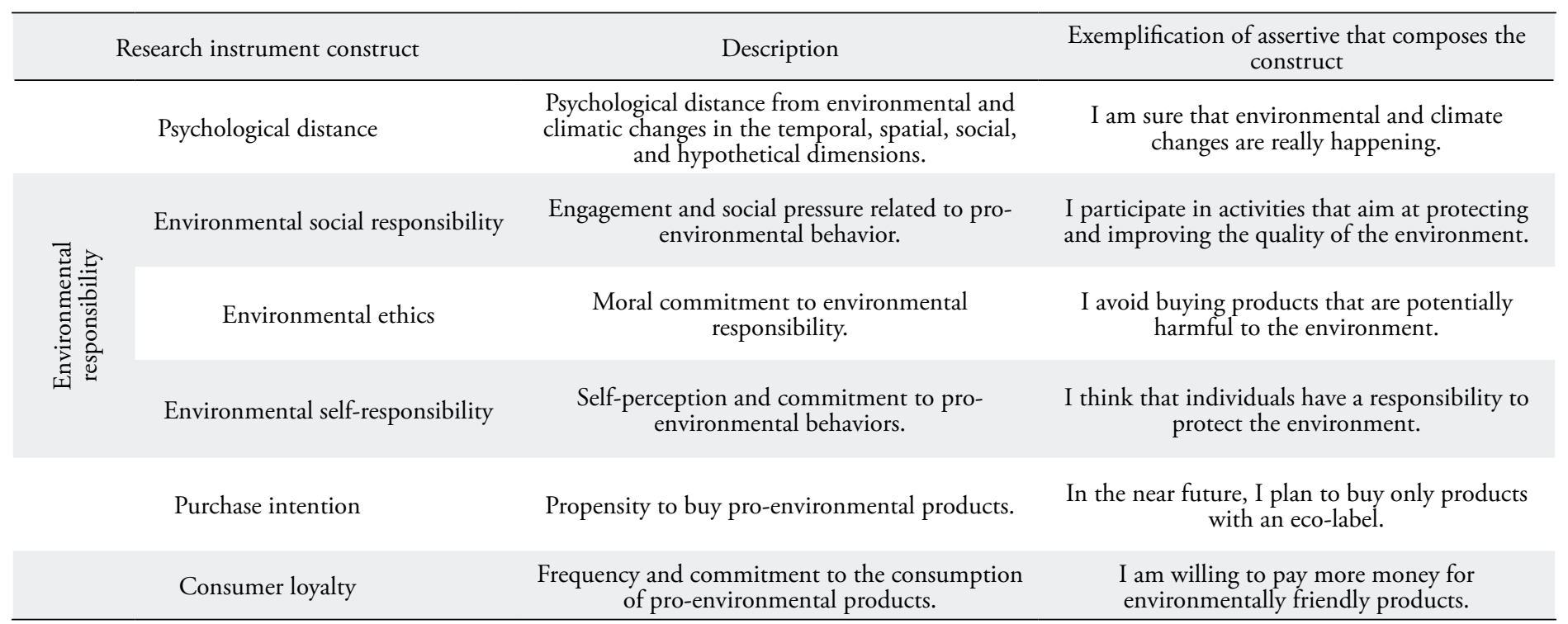

Note. Source: research data.

It should be noted that the construct of environmental responsibility is made up of three second-order constructs (environmental social responsibility, environmental ethics, and environmental self-responsibility). The second block was designed to characterize respondents, with questions regarding the participant's profile.

The questionnaire was submitted to a validation process in September 2017, consisting of three stages: (1) content validation; (2) apparent validation; and (3) pre-test. The content validation was performed by two professors and researchers linked to a stricto sensu graduate program and who have a research history in the area of interest. The objective of this step was to verify whether the content of the statements had the capacity to characterize the constructs addressed for research. Some contributions were directed toward improving the assertions, for example, ex ante - 'I feel more comfortable when I use ecological products instead of normal ones' and ex post - 'I feel more comfortable when I use ecological products instead of non-ecological ones'.

Apparent validation was performed by two researchers with a research history and teaching experience in undergraduate courses, with the aim 
of verifying the understanding of the scale. Thus, the participants were asked individually to read aloud each statement and then to explain their understanding of the item addressed. New contributions were obtained in this step, following the suggestion that the statement 'I support non-governmental organizations that work to minimize negative impacts on the environment' should be changed to 'I support non-governmental organizations that work to minimize negative impacts caused by other organizations to the environment.' Finally, a pre-test was carried out with nine undergraduate students who did not compose the final sample of the research; at this stage, there was no suggestion for improvement.

Data collection was carried out on site in night classes, with the consent of the teachers, through printed questionnaires applied in November 2017. We chose faceto-face collection so that the greatest possible number of respondents was reached, and if the participant had any doubts about the objective of the research, he or she could clarify it with the researchers.

In the data analysis, the structural equation modeling technique with partial least squares measurement model (PLS-SEM) was calculated using the variance (VB-SEM). According to Hair, Sarstedt, Ringle and Mena (2012) the use of the VB-SEM calculation allows the researcher to estimate complex models with a reduced number of sample components. This fact is one of the justifications for the increasing use of this technique in research related to applied social sciences, since the use of primary data is one of the challenges to be overcome in studies in this area of knowledge.

The suitable sample size for the application of structural equation modeling was estimated using the $G^{*}$ Power 3.1.9.2 $2^{\circ}$ software. For this purpose, the effect size $\mathrm{f}^{2}=0,15, \alpha$ err prob $=0,05$ and $1-\beta$ err prob $=$ 0,8 were defined as median. The minimum sample size returned was 68 responses, as 113 valid participations were obtained. The prerequisites for applying the PLSSEM technique were met. Data verification was guided by the analysis protocol shown in Table 2 .

Data analysis was performed using the $\mathrm{R}$ Studio $1.0 .153^{\circ}$ software cwith the plspm package.

Table 2. Analysis protocol.

\begin{tabular}{|c|c|c|c|c|}
\hline & Stage & Objective & Parameter & Reference \\
\hline \multicolumn{2}{|c|}{ Descriptive statistics } & $\begin{array}{l}\text { Describe the percentage values referring to the } \\
\text { characteristics of the respondents. }\end{array}$ & There isn't. & The authors (2017) \\
\hline \multirow{5}{*}{ 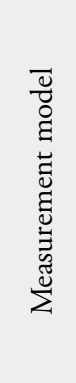 } & $\begin{array}{l}\text { Average variance } \\
\text { extracted - AVE }\end{array}$ & $\begin{array}{l}\text { Measure the portion of the data (in the respective } \\
\text { variables) that is explained by each of the constructs. }\end{array}$ & Values above 0.50 & $\begin{array}{l}\text { Henseler, Ringle and Sinkovics } \\
\text { (2009) }\end{array}$ \\
\hline & DG. Rho & \multirow{3}{*}{$\begin{array}{l}\text { Evaluate the reliability and the internal grouping } \\
\text { capacity of the construct. }\end{array}$} & Values above 0.7 & \multirow{3}{*}{ Sanchez (2013) } \\
\hline & 1st eigenvalue & & Values above 1. & \\
\hline & 2nd eigenvalue & & Values below 1 . & \\
\hline & Cross factorial loads & $\begin{array}{l}\text { Evaluate the independence of the latent variables } \\
\text { observed in relation to the others. }\end{array}$ & $\begin{array}{l}\text { Values above } 0.5 \text { and highest } \\
\text { crossing value. }\end{array}$ & $\begin{array}{l}\text { Hair, Hult, Ringle and Sarstedt } \\
\text { (2014); Sanchez (2013) }\end{array}$ \\
\hline \multirow{4}{*}{ 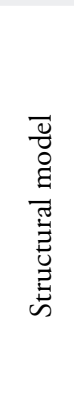 } & Coefficient estimates & $\begin{array}{l}\text { Evaluate the significance of coefficients and } \\
\text { endogenous regressions ( } t \text { test). }\end{array}$ & $\begin{array}{l}\text { Significant } \mathrm{p} \text {-value by up to } \\
10 \% \text {. }\end{array}$ & \multirow{2}{*}{ Sanchez (2013) } \\
\hline & $\begin{array}{l}\text { Correlations between } \\
\text { latent variables }\end{array}$ & Evaluate the correlation between latent variables. & $\begin{array}{l}\text { Relevant correlations, above } \\
0.5 \text {. }\end{array}$ & \\
\hline & $\mathrm{R}^{2}$ & $\begin{array}{l}\text { Evaluate the explanatory power of exogenous to } \\
\text { endogenous variables. }\end{array}$ & $\begin{array}{l}\text { Up to } 2 \% \text {, small effect; above } \\
2 \% \text { to } 13 \% \text {, medium effect; } \\
\text { above } 13 \% \text { up to } 26 \% \text {, large } \\
\text { effect. }\end{array}$ & Cohen (1988) \\
\hline & Goodness-of-Fit (GoF) & Check the fit of the model. & Above 0.36 & $\begin{array}{l}\text { Tenenhaus, Vinzi, Chatelin and } \\
\text { Lauro (2005); Sanchez (2013) }\end{array}$ \\
\hline
\end{tabular}

Note. Source: prepared by the authors. 


\section{DATA ANALYSIS}

\section{Profile of respondents}

The profile of respondents is shown in Table 3, based on percentages related to gender, age group, marital status, and occupation of respondents.
Of the 113 participations analyzed, 64 (56.64\%) are male. Regarding age, 49 students (43.36\%) are under 20 years old. Currently, 86 respondents $(76.10 \%)$ work or do an internship, while 97 students (85.84\%) have a single marital status.

Table 3. Descriptive statistics.

\begin{tabular}{ccccc}
\hline & \multicolumn{3}{c}{ Respondents profile } \\
\hline & Gender & \multicolumn{3}{c}{ Do you currently work or do an internship? } \\
\hline Male & $56.64 \%$ & Yes & $76.10 \%$ \\
Female & $43.36 \%$ & No & What is your marital status? \\
\hline What is your age group? & \multicolumn{3}{c}{ Not married } & $85.84 \%$ \\
\hline Up to 20 years & $43.36 \%$ & Married & $10.62 \%$ \\
$21-25$ years & $33.63 \%$ & Divorced & $0.88 \%$ \\
$26-30$ years & $14.16 \%$ & Stable relationship & $1.77 \%$ \\
$31-35$ years & $4.42 \%$ & Widower & $0.88 \%$ \\
$36-40$ years & $2.66 \%$ & & \\
Above 40 years & $1.77 \%$ & &
\end{tabular}

Note. Source: research data.

\section{Analysis of the measurement model}

The structural equation modeling technique consists of two models: measurement and structural. The measurement model seeks to analyze the internal validity of the constructs from the unidimensionality of the indicators, whose objective is to identify whether the statements reflect the latent variable that they propose to measure (Hair, Hult, Ringle \& Sarstedt, 2014), with this verification being carried out from the DG. Rho and the first and second eigenvalues (Sanchez, 2013).

The DG. Rho verifies the variance of the sum of the latent variable indicators. Values above 0.70 indicate the existence of unidimensionality in the construct. This indicator is considered more efficient than Cronbach's alpha (Sanchez, 2013); in view of this, we opted to only analyze the DG. Rho. The first and second eigenvalues show the correlations between the indicators, with the first eigenvalue and the second eigenvalue being respectively greater and less than 1 to indicate the existence of unidimensionality.

Initially, it was necessary to exclude statement 4 from psychological distance and statement 11 from ethical behavior because they impair the unidimensionality of the constructs. Then, the evaluation of internal consistency and convergent validity was performed, through the AVE (Hair et al., 2014). The AVE "measures the amount of variance that a latent variable captures from its indicators in relation to the amount of variance due to the measurement error" (Sanchez, 2013, p. 104), with values above 0.50 being considered appropriate. Table 4 shows the correlations of the constructs and the indicators of internal reliability and convergent validation.

The evaluation of the correlations of the constructs allows identifying the intensity with which the latent variables are associated (Sanchez, 2013). From Table 4, it can be seen that psychological distance has a higher level of positive association with environmental self-responsibility $(\mathrm{r}=0.393)$. Environmental social responsibility is positively correlated to environmental ethics $(r=0.695)$, while the purchase intention also shows positive coefficients of association to environmental social responsibility $(r=0.761)$, environmental self-responsibility $(r=0.783)$, and consumer loyalty $(\mathrm{r}=0.701)$. 
Table 4. Construct correlations, internal reliability, and convergent validation.

\begin{tabular}{|c|c|c|c|c|c|c|}
\hline Variables & $\begin{array}{l}\text { Psychological } \\
\text { distance }\end{array}$ & $\begin{array}{l}\text { Environmental } \\
\text { ethics }\end{array}$ & $\begin{array}{l}\text { Environ-mental } \\
\text { social responsibility }\end{array}$ & $\begin{array}{l}\text { Environmental self- } \\
\text { responsibility }\end{array}$ & Purchase intention & Consumer loyalty \\
\hline $\begin{array}{l}\text { Psychological } \\
\text { distance }\end{array}$ & 1.000 & & & & & \\
\hline $\begin{array}{l}\text { Environmental } \\
\text { ethics }\end{array}$ & 0.383 & 1.000 & & & & \\
\hline $\begin{array}{c}\text { Environmental } \\
\text { social responsibility }\end{array}$ & 0.303 & 0.695 & 1.000 & & & \\
\hline $\begin{array}{l}\text { Environmental self- } \\
\text { responsibility }\end{array}$ & 0.393 & 0.672 & 0.703 & 1.000 & & \\
\hline Purchase intention & 0.361 & 0.638 & 0.761 & 0.783 & 1.000 & \\
\hline Consumer loyalty & 0.212 & 0.592 & 0.706 & 0.675 & 0.701 & 1.000 \\
\hline DG. Rho & 0.895 & 0.807 & 0.860 & 0.865 & 0.903 & 0.891 \\
\hline $1^{\text {st }}$ eigenvalue & 2.22 & 2.06 & 2.77 & 2.47 & 3.26 & 3.11 \\
\hline $2^{\text {nd }}$ eigenvalue & 0.486 & 0.846 & 0.943 & 0.926 & 0.793 & 0.870 \\
\hline AVE & 0.730 & 0.506 & 0.553 & 0.616 & 0.652 & 0.616 \\
\hline
\end{tabular}

Note. Parameters (Henseler, Ringle, \& Sinkovics, 2009; Sanchez, 2013): DG. Rho $>0,70 ; 1^{\text {st }}$ eigenvalue $>1 ; 2^{\text {nd }}$ eigenvalue $<1 ;$ AVE $>0.50$. Source: research data.

The smallest associations are found between psychological distance and other variables. In this sense, it is important to highlight that the correlation is based on an assumption of linear relationship, in which the increase in one variable is associated with a change in another variable. As it is a study linked to human behavior, which is shaped from different elements and contexts, the relationships found can be considered satisfactory, as Cohen (1988) highlights that correlations between 0.10 and 0.49 can be classified as medium or small depending on the range of values in which they are found.

When checking the DG. Rho, it is noted that all constructs meet the parameter defined by this indicator, with coefficients above 0.70 being presented. In addition, the criteria defined for the first and the second eigenvalues were met, as well as the premise of the AVE. These results show the internal reliability of the constructs and confirm their convergent validity.

In order to finalize the evaluation of the measurement model, the discriminating validity of the indicators must be examined by means of cross-loadings, in which the independence of the latent variables in relation to the others is verified (Hair et al., 2014). Sanchez (2013)ccites the need for the loadings of each construct to be higher than the others and greater than 0.50 . Table 5 shows the maximum and minimum coefficients of the own crossloadings and of the other crossings.

Table 5. Discriminant validity — cross-loadings.

\begin{tabular}{lcccc}
\hline \multicolumn{1}{c}{ Discriminant validity } & Cross loads (minimum) & Cross loads (maximum) & $\begin{array}{c}\text { Associated construct } \\
\text { (minimum) }\end{array}$ & $\begin{array}{c}\text { Associated construct } \\
(\text { maximum) }\end{array}$ \\
\hline Psychological distance & 0.067 & 0.394 & 0.772 & 0.899 \\
Environmental ethics & 0.147 & 0.631 & 0.704 & 0.743 \\
Social responsibility & 0.088 & 0.675 & 0.611 & 0.861 \\
Social self-responsibility & 0.306 & 0.658 & 0.773 & 0.840 \\
Purchase intention & 0.243 & 0.689 & 0.703 & 0.870 \\
Consumer loyalty & 0.020 & 0.719 & 0.642 & 0.884 \\
\hline
\end{tabular}

Note. Parameters (Hair et al., 2014; Sanchez, 2013): minimum values of the associated construct above 0.50. In addition, the lower value of the associated construct must be greater than the values of the cross loads. Source: research data (2017). 
As shown in Table 5, the values obtained in crossloadings are above 0.50 , indicating that the statements of the latent variables can explain at least $50 \%$ of the construct (Sanchez, 2013). In general, cross-loadings are higher than the values of the other constructs, indicating that there is independence between the latent variables studied. From the analysis of internal reliability and the convergent and discriminant validations, it is possible to state that the measurement model is adequate and is able to represent the latent variables that it is proposed to measure.

\section{Structural model and research hypothesis}

The evaluation of the structural model and the research hypothesis are carried out jointly. To verify whether the relationship between psychological distance with purchase intention and loyalty to pro-environmental products is mediated by environmental responsibility, premises (a), (b), and (c) by Baron and Kenny (1986).

First, the premises (a) and (b) that consider the coefficients of direct effects between the path constructs that contain the presumed latent mediating variables were analyzed. Premise (a) aims at identifying whether there are direct and significant effects on the path coefficients obtained between the psychological distance and the latent variables of environmental responsibility. Premise (b) evaluates the existence of direct and significant effects between the path coefficients of environmental responsibility, the purchase intention, and consumer loyalty. Through Table 6 it is possible to analyze the results obtained.

Table 6. Path evaluation.

\begin{tabular}{|c|c|c|c|}
\hline Premise & Path & Direct effect & Conclusion \\
\hline \multirow{3}{*}{ (A) } & Psychological distance $>$ Environmental ethics & $0.382^{* * *}$ & \multirow{3}{*}{ Attended premise } \\
\hline & Psychological distance $>$ Environmental social responsibility & $0.302^{* * *}$ & \\
\hline & Psychological distance $>$ Environmental social responsibility & $0.393^{* * *}$ & \\
\hline \multirow{6}{*}{ (B) } & Environmental ethics $>$ Purchase intention & $0.032^{* * *}$ & \multirow{6}{*}{ Attended premise } \\
\hline & Environmental ethics $>$ Consumer loyalty & $0.102^{* * *}$ & \\
\hline & Environmental social responsibility > Purchase intention & $0.399^{* * *}$ & \\
\hline & Environmental social responsibility > Consumer loyalty & $0.416^{* * *}$ & \\
\hline & Environmental self-responsibility > Purchase intention & $0.462^{* * *}$ & \\
\hline & Environmental self-responsibility > Consumer loyalty & $0.349^{* * *}$ & \\
\hline
\end{tabular}

Note. Baron and Kenny's (1986) assumptions: (a) variations in the levels of the independent variable (psychological distance) significantly affect the variations of the assumed mediator (environmental ethics, environmental social responsibility, and environmental self-responsibility); and (b) variations in the possible mediator (environmental ethics, environmental social responsibility, and environmental self-responsibility) significantly affect variations in the dependent variable (purchase intention and consumer loyalty). *** indicate significance at the level of $1 \%$. Source: research data (2017).

From the provisions in Table 6, it is noted that all the path coefficients that represent the direct effects were significant at the level of $1 \%$, with premises (a) and (b) being met. The results indicate a positive relationship in all observed trajectories. Psychological distance has a greater direct effect on environmental self-responsibility ( $\beta$ $=0.393 ; \mathrm{p}$-value $<0.01)$, indicating that the closer the individual perceives climatic changes in spatial, temporal, social, and hypothetical terms, the greater the level of self-responsibility reflected in altruism and well-being. This finding corroborates Brügger et al. (2016) insofar as psychological distance is able to influence the behavior and judgment of individuals. It is also corroborated by McDonald et al. (2015), since this variable is a predictor of environmental responsibility.
Environmental ethics $(\beta=0,102$; $p$-value $<0,01)$ and environmental social responsibility $(\beta=0.416$; p-value $<0.01)$ have a greater direct effect on consumer loyalty, indicating that elements inherent to moral and to social pressure have a greater capacity to affect the loyalty of the study participants in relation to the consumption of pro-environmental products and brands. On the other hand, the purchase intention is directly and more strongly influenced by environmental self-responsibility $(\beta=0.462$; $\mathrm{p}$-value $<0.01)$, pointing out that the desire to consume pro-environmental products comes from the individual's own judgments about his role and commitment to society.

In order to verify the existence of mediation on the part of environmental responsibility in the relationship between psychological distance with the purchase intention and consumer loyalty, an analysis of the last premise by 
Baron and Kenny (1986) was carried out. Premise (C) consists of the decrease or extinction of the significant direct effect between the independent and dependent variables from the inclusion of the presumed mediating variable.
Tables 7 and 8 show the values of the path coefficients of the model without mediation and with mediation, as well as the explanatory power of the relationship network over exogenous variables.

Table 7. Structural model and mediation evaluation.

\begin{tabular}{|c|c|c|c|c|c|c|c|c|}
\hline \multirow{3}{*}{ Premise (c) } & \multirow{3}{*}{$\begin{array}{c}\begin{array}{c}\text { Model without } \\
\text { mediation }\end{array} \\
\text { Effect } \\
\beta \\
\end{array}$} & \multicolumn{6}{|c|}{ Model with mediation considering academic performance } & \multirow{3}{*}{$\begin{array}{l}\mathrm{H}_{1} \\
\text { mediation }\end{array}$} \\
\hline & & \multicolumn{2}{|c|}{ Direct effect } & \multicolumn{2}{|c|}{ Indirect effect } & \multirow{2}{*}{$\begin{array}{c}\text { Total effect } \\
\beta \\
\end{array}$} & \multirow{2}{*}{$\begin{array}{c}\text { Mediation effect } \\
\%\end{array}$} & \\
\hline & & $\beta$ & $\%$ & $\beta$ & $\%$ & & & \\
\hline $\begin{array}{l}\text { Psychological distance } \\
>\text { Purchase intention }\end{array}$ & $0.372^{* * *}$ & $0.045^{* * *}$ & 12.50 & 0.315 & 87.50 & $0.360^{* *}$ & +87.50 & Partial \\
\hline $\begin{array}{l}\text { Psychological distance } \\
>\text { Consumer loyalty }\end{array}$ & $0.237^{* *}$ & $-0.090^{* * *}$ & -42.65 & 0.303 & 142.65 & $0.211^{* *}$ & +142.65 & Total \\
\hline
\end{tabular}

Note. Premisse of Baron and Kenny (1986):(c) is met with the decrease or lack of significant direct effects between the independent variable (psychological distance) and the dependent one (purchase intention and consumer loyalty) with the inclusion of the presumed variable mediator (environmental ethics, environmental social responsibility, and environmental self-responsibility). If by including the presumed mediating variable the direct effect is reduced to zero, with the significant effects of premises (a) and (b) remaining, it is possible to affirm the existence of total mediation; if this reduction is not to zero, then there is partial mediation. $\beta=$ Beta; $\%=$ Percentage of the effect. *** and ${ }^{* *}$ indicate significance at the level of $1 \%$ and $5 \%$, respectively. Source: research data (2017).

Table 8. Explanatory power of the evaluated models.

\begin{tabular}{lcc}
\hline \multicolumn{1}{c}{ Construct } & $\mathrm{R}^{2}-$ Model without mediation & $\mathrm{R}^{2}-$ Model with mediation \\
\hline Environmental ethics & There is not & $0.146^{* *}$ \\
Environmental social responsibility & There is not & $0.091^{* *}$ \\
Environmental self-responsibility & There is not & $0.154^{* *}$ \\
Buy intention & $0.138^{* *}$ & $0.703^{* *}$ \\
Consumer loyalty & $0.056^{* *}$ & $0.571^{* *}$ \\
Goodness-of-Fit (GoF) & 0.25 & 0.45 \\
\hline
\end{tabular}

Note. $\mathrm{R}^{2}$ = Explanatory power of exogenous variables for endogenous ones; Goodness-of-Fit = Model adjustment power. Parameters (Cohen, 1988; Tenenhaus, Vinzi, Chatelin \& Lauro, 2005): $\mathrm{R}^{2}$ up to $2 \%$ indicates a small effect; above $2 \%$ to $13 \%$ indicates a medium effect; above $13 \%$ up to $26 \%$ indicates a large effect; and GoF above 0.36 is adequate. ** indicate significance at the level of 5\%. Source: research data (2017).

Through the path analysis carried out from the premises of Baron and Kenny (1986) and instrumentalized with the aid of the bootstrapping method, the existence of partial mediation of the constructs of environmental responsibility in the relationship between psychological distance, purchase intention, and consumer loyalty was identified.

Environmental responsibility has a partial mediation between psychological distance and the purchase intention, as the direct effect declines in its coefficient with the inclusion of mediation. In percentage terms, environmental responsibility mediates $87.50 \%$ of the effects of the analyzed relationship. In turn, when verifying the path between psychological distance and consumer loyalty, it is noted that environmental responsibility exercises total mediation in this relationship, a fact observed from the significance obtained in the analysis of the coefficients and in the reduction of direct effects.
Such results differ from the findings by Yu et al. (2017) $\mathrm{n}$ to the extent that the entire chain of environmental responsibility mediated the relationship between psychological distance, the purchase intention, and consumer loyalty. These results may come from differences in the design of the structural model, since in this investigation, environmental ethics was considered at the same level as the self and social standards of responsibility.

The significance between environmental responsibility and consumer loyalty is in line with the evidence exposed by Oliver (1999), because in his study, this relationship is elucidated. Additionally, the findings of Kautish andSharma (2019) and Shafiei and Maleksaeidi (2020) support the importance of studying behavioral aspects in the face of consumer behavior, especially of young university students, as these variables have predictive power in relation to their attitudes. 
The results obtained through the analysis of the data allow not to reject the hypothesis proposed in this research that the relationship between psychological distance, the purchase intention, and loyalty to pro-environmental products is mediated by environmental responsibility, since the objective of the proposition consists in identifying the existence of the mediating phenomenon, a fact that was confirmed through path analysis. In terms of intensity, it is noted that such mediation occurs partially in the path between environmental responsibility and purchase intention, and total between environmental responsibility and consumer loyalty.

As for the proposed model, all the $\mathrm{R}^{2}$ of the constructs showed significance at the level of $5 \%$, and the structural model with mediation had greater predictive power since the Goodness-of-Fit of the model with mediation was 0.45 compared to 0.25 of the direct model. Thus, one perceives the relevance in addressing the mediating effect of environmental responsibility in the analysis of the behavior of young university students in the Accounting course, who represent the consumers analyzed in this research.

Regarding psychological distance, it can be seen from the results that the individual's lower distance from climate change promotes environmental responsibility, being in agreement with the discussions by Spence et al. (2012). The approach with respondents in order to retract the psychological distance from climate change becomes opportune from the promotion of environmental responsibility, since the results indicate that this variable is able to fully mediate the relationship between psychological distance and loyalty of the consumer.

Based on the exposed results and the elements inherent to the theory of the level of interpretation, environmental responsibility can be promoted in students of the Accounting Sciences course through environmental awareness practices and actions aimed at exposing the impacts of climate and environmental changes. It is believed that educational campaigns, interactive activities, and extension projects that explore the consequences of consumption patterns on environmental changes can help reduce the existing psychological distance.

\section{CONCLUSION}

This study aimed at verifying the relationship between psychological distance, the purchase intention, and loyalty to pro-environmental products mediated by environmental responsibility. For that, the data collection was instrumentalized through a survey carried out with academics from the Bachelor in Accounting Sciences from a public university in southern Brazil. In the analysis of the data, the technique of structural equation modeling, bootstrapping method, and the premises of Baron e Kenny (1986) were used to verify the proposed hypothesis.

The identification of the significant mediating effect of environmental responsibility made it possible for the research hypothesis not to be rejected, as in terms of intensity it was identified that environmental responsibility partially mediates the relationship between psychological distance and purchase intention, and totally mediates the relationship with consumer loyalty. The results also indicate that the mediating model has greater predictive power and is more suitable for analyzing the consumption behavior of academics in the Accounting Sciences course. Such findings lead to theoretical and practical implications about the theme, which are discussed below.

\section{Theoretical implications}

This study extends the body of existing theoreticalempirical literature by pointing out that an understanding of environmental responsibility is a key element in identifying purchase intent and loyalty to pro-environmental products. In addition, the need to observe variables that expand discussions about behavioral predictors is reinforced, in addition to observable characteristics, such as gender and age, commonly addressed in the literature. The elements of the interpretation level theory proved to be adequate and pertinent to the analysis of the behavior of young consumer university students belonging to the Accounting Sciences course, since the psychological distance can affect the purchase intention and loyalty of these consumers.

Environmental responsibility, with emphasis on environmental ethics, presents itself as a predictor of the behavior of young university students who make up the research sample. Ethics has been identified as an important element and one that raises concerns regarding the training of Accounting professionals. When verifying the relationship of this construct with the purchase intention and loyalty to pro-environmental products, the need to address ethics in its different dimensions is reinforced in order to detect behavioral patterns and relate them to corrective measures of future behavior.

In relation to consumers in general, the interpretation level theory brings relevant elements that can be extended to this broad audience in order to encourage the discussion of consumer behavior, since when illustrating that events perceived close to university students tend to receive more attention and importance in judgments and personal attitudes, opportunities for research and practical actions are opened in different areas of the behavioral scope. For example, advertising campaigns can guide the benefits of conscious consumption based on short-term effects on the environment in order to promote individual engagement. 


\section{Practical implications}

The results found indicate that psychological distance can foster conscious behavior in respondents, and it is opportune to invest in advertising campaigns, educational actions, and activities that reduce the notion of distance from environmental impacts. The theoretical elements indicate that the financial factor and the perceived quality are taken into account in the process of purchasing pro-environmental products, so consumption and social inclusion policies can be developed to indirectly encourage the purchase and use of pro-environmental products. It also highlights the need to emphasize the role of pro-environmental products in helping environmental sustainability and self-responsibility with the environment, therefore advertising communications aimed at university students in the Accounting area should focus on the social effects of consuming such products in the short term and not strictly on the financial side.

In relation to Accounting students, it is opportune to include discussions about environmental responsibility, based on contentaimed atconscious consumption and environmental sustainability. Disciplines such as Environmental Accounting can cover in their topics elements that deal with social and ethical values, showing the importance of environmental responsibility in social terms, expanding classroom debates beyond the financial aspects that permeate the creation of economic value for the organization. It is believed that such debates may assist in the training of Accounting professionals concerned and aligned with environmental issues.

\section{REFERENCES}

Afonso, M. H. F., Bornia, A. C., Echegaray, F., \& de Andrade, D. F. (2016). Comportamento de consumo sustentável: Mensuração com o uso da teoria da resposta ao item. Revista Eletrônica de Gestão Organizacional, 14, 16-29. http://dx.doi.org/10.21714/1679-18272016v14Esp.p16-29

Ariztía, T., Kleine, D., Brightwell, M. das G. S. L., Agloni, N., Afonso, R., \& Bartholo, R. (2014). Ethical consumption in Brazil and Chile: Institutional contexts and development trajectories. Journal of Cleaner Production, 63, 84-92. https://doi.org/10.1016/j.jclepro.2013.04.040

Baron, R. M., \& Kenny, D. A. (1986). The moderator-mediator variable distinction in social psychological research: Conceptual, strategic, and statistical considerations. Journal of personality and social psychology, 51(6), 1173-1182. http://doi.org/10.1037//0022-3514.51.6.1173

Brügger, A., Morton, T. A., \& Dessai, S. (2016). "Proximising" climate change reconsidered: A construal level theory perspective. Journal of Environmental Psychology, 46, 125142. http://doi.org/10.1016/j.jenvp.2016.04.004

\section{Limitations and future research}

Further investigations on the subject are made available, addressing the constructs of psychological distance and environmental responsibility simultaneously and together with consumer behavior. Researches can adopt qualitative data collection and analysis techniques to identify the respondents' perception about the theme in depth. In addition, environmental responsibility can be tested in future investigations as a moderator of the relationship between psychological distance and consumer behavior. Covering the sample for other areas of knowledge and for consumers with different profiles also presents itself as a research opportunity.

The limitations of the research come from the nonprobabilistic choice of the sample. The respondents are young consumers with access to information on the environmental theme and may not represent the Brazilian reality and the cross-sectional time frame limits the inferential power of the results. Finally, it is considered that this investigation has reached the proposed objective and exposed insights for future investigations in that area of research.

\section{ACKNOWLEDGEMENTS}

The authors would like to thank the researcher Iago França Lopes (UFPR) for the previous review of this article.

Chen, Y. S. (2011). Green organizational identity: sources and consequence. Management Decision, 49(3), 384-404. http://doi.org/10.1108/00251741111120761

Cohen, J. (1988). Statistical Power Analysis for the behavioral sciences (2nd ed). New York: Psychology Press.

Eckhardt, G. M., Belk, R., \& Devinney, T. M. (2010). Why don't consumers consume ethically?. Journal of Consumer Behaviour, 9(6), 426-436. https://doi.org/10.1002/b.332

Fakhrudin, I. A., Karyanto, P., \& Ramli, M. (2018). Behavioral intention and its relationship with gender: a study of green school students in Surakarta, Indonesia. Journal of Physics: Conference Series, 1022(1), 012043. http://doi.org/10.1088/1742-6596/1022/1/012043

Ferraz, S. B., Romero, C. A. B., Rebouças, S. M. D. P., \& Costa, J. S. (2016). Produtos verdes: Um estudo sobre atitude, intenção e comportamento de compra de universitários brasileiros. Revista de Administração da UFSM, 9(4), 605623. http://doi.org/10.5902/1983465912400 
Gordon-Wilson, S., \& Modi, P. (2015). Personality and older consumers' green behaviour in the UK. Futures, 71, 1-10. https://doi.org/10.1016/j.futures.2015.05.002

Gilead, M., Liberman, N., \& Maril, A. (2014). From mind to matter: Neural correlates of abstract and concrete mindsets. Social Cognitive and Affective Neuroscience, 9(5), 638-645. http://doi.org/10.1093/scan/nst031

Global Industry Analysts. (2013). Green marketing: A global strategic business report. Retrieved from: http://www. asiagreenbuildings.com/3553/green-marketing-a-globalstrategic-business-report/

Groening, C., Sarkis, J., \& Zhu, Q. (2018). Green marketing consumer-level theory review: A compendium of applied theories and further research directions. Journal of Cleaner Production, 172, 1848-1866. http://doi.org/10.1016/j.jclepro.2017.12.002.

Hair, J. F., Jr., Hult, G. T. M., Ringle, C. M., \& Sarstedt, M. (2014). A primer on partial least squares structural equation modeling (PLS-SEM). Thousand Oaks: SAGE.

Hair, J. F., Sarstedt, M., Ringle, C. M., \& Mena, J. A. (2012). An assessment of the use of partial least squares structural equation modeling in marketing research. Journal of the Academy of Marketing Science, 40(3), 414-433. https://doi.org/10.1007/s11747-011-0261-6

Henseler, J., Ringle, C. M., \& Sinkovics, R. R. (2009). The use of partial least squares path modeling in international marketing. Advances in International Marketing, 20, 277-319. https://doi.org/10.1108/S1474-7979(2009)0000020014

Institute of Medicine (US), Roundtable on Environmental Health Sciences, Research, and Medicine. (2007). Global environmental health in the 21st Century: From Governmental Regulation to Corporate Social Responsibility: Workshop Summary. Washington, DC: National Academies Press, 5, Corporate Social Responsibility. Retrieved from: https://www.ncbi.nlm.nih.gov/books/NBK53982/

Instituto Brasileiro de Geografia e Estatística. (2020). Pirâmide Etária. Retrieved from: https://educa.ibge.gov.br/jovens/ conheca-o-brasil/populacao/18318-piramide-etaria.html

Joshia, Y., \& Rahman, Z. (2015). Factors affecting green purchase behaviour and future research directions. International Strategic Management Review, 3(1-2), 128-143. https://doi.org/10.1016/j.ism.2015.04.001

Khan, H. Z., Fatima, J. K., \& Bose, S. (2019). Understanding pro-environmental behaviour of accounting and business students: Development of a conceptual framework. Ethics and Sustainability in Accounting and Finance, 1, 69-82. http://doi.org/10.1007/978-981-13-3203-6 5

Kautish, P., \& Sharma, R. (2019). Study on relationships among terminal and instrumental values, environmental consciousness and behavioral intentions for green products. Journal of Indian Business Research. https://doi.org/10.1108/JIBR-01-2018-0013.

Kelly, M., \& Alam, M. (2009). Educating accounting students in the age of sustainability. Australasian Accounting, Business and Finance Journal, 3(4), 3. Retrieved from: https://ro.uow.edu.au/aabf//vol3/iss $4 / 3 /$
Lecours, V., Devillers, R., Schneider, D. C., Lucieer, V. L., Brown, C. U. J., Edinger, E. J. (2015). Spatial scale and geographic context in benthic habitat mapping: review and future directions. Marine Ecology Progress Series, 535, 259-284. http://doi.org/10.3354/meps11378

Lee, Y.K. (2017). A comparative study of green purchase intention between Korean and Chinese consumers: The moderating role of collectivism. Sustainability, 9(10), 1930. https://doi.org/10.3390/su9101930

McCabe, D. L., Butterfield, K. D., \& Trevińo, L. K. (2006). Academic dishonesty in graduate business programs: Prevalence, causes, and proposed action. Academy of Management Learning and Education, 5(3), 294-305. https://doi.org/10.5465/amle.2006.22697018

McDonald, R. I., Chai, H. Y., \& Newell, B. R. (2015). Personal experience and the 'psychological distance' of climate change: An integrative review. Journal of Environmental Psychology, 44, 109-118. https://doi.org/10.1016/j.jenvp.2015.10.003

Meriac, J. P. (2012). Work ethic and academic performance: Predicting citizenship and counterproductive behavior. Learning and Individual Differences, 22(4), 549-553. https://doi.org/10.1016/j.lindif.2012.03.015

Mohiuddin, M., Al Mamun, A., Syed, F. A., Masud, MM., \& Su, Z. (2018). Environmental knowledge, awareness, and business school students' intentions to purchase green vehicles in emerging countries. Sustainability, 10(5), 1534. https://doi.org/10.3390/su10051534

Oliver, R. L. (1999). Whence consumer loyalty? The Journal of Marketing, 63, 33-44. https://doi.org/10.2307/1252099

Sacchi, S., Riva, P., \& Aceto, A. (2016). Myopic about climate change: Cognitive style, psychological distance, and environmentalism. Journal of Experimental Social Psychology, 65, 68-73. https://doi.org/10.1016/j.jesp.2016.03.006

Sanchez, G. (2013). PLS path modeling with R. Berkeley: Trowchez Editions.

Serviço de Proteção ao Crédito. (2019). Consumo Consciente 2019. Retrieved from: https://www.spcbrasil.org.br/ wpimprensa/wp-content/uploads/2019/06/analise compras online junho 2019.pdf

Shafiei, A., \& Maleksaeidi, H. (2020). Pro-environmental behavior of university students: Application of protection motivation theory. Global Ecology and Conservation, 22, e00908. https://doi.org/10.1016/j.gecco.2020.e00908

Singh, A. S., Zwickle, A., Bruskotter, J. T., \& Wilson, R. (2017). The perceived psychological distance of climate change impacts and its influence on support for adaptation policy. Environmental Science \& Policy, 73, 93-99. https://doi.org/10.1016/j.envsci.2017.04.011

Spence, A., Poortinga, W., \& Pidgeon, N. (2012). The psychological distance of climate change. Risk Analysis, 32(6), 957-972. http://doi.org/10.1111/j.1539-6924.2011.01695.x

Tenenhaus, M., Vinzi, V.E., Chatelin, Y \& Lauro, C. (2005). PLS path modeling. Computational Statistics \& Data Analysis. 48(1), 159-205. https://doi.org/10.1016/j.csda.2004.03.005 
Trenberth, K. E. (2012). Framing the way to relate climate extremes to climate change. Climatic change, 115, 283-290. https://doi.org/10.1007/s10584-012-0441-5

Trivedi, R. H., Patel, J. D., \& Acharya, N. (2018). Causality analysis of media influence on environmental attitude, intention and behaviors leading to green purchasing. Journal of cleaner production, 196, 11-22. https://doi.org/10.1016/j.jclepro.2018.06.024

Trope, Y., \& Liberman, N. (2010). Construal-level theory of psychological distance. Psychological review, 117(2), 440463. http://doi.org/10.1037/a0018963

United States of America. Environmental Protection Agency. (2015). Laws \& Regulations. Retrieved from: http://www2.epa.gov/laws-regulations

\section{Authorship}

\section{Alison Martins Meurer*}

Universidade Federal do Paraná, Programa de Pós-Graduaçáo em Contabilidade

Av. Prefeito Lothário Meissner, $n^{\circ}$ 632, Jardim Botânico, 80210-170, Curitiba, PR, Brazil.

E-mail address: alisonmmeurer@gmail.com

(1) https://orcid.org/0000-0002-3704-933X

\section{Cristina Viana de Jesus}

Universidade Federal do Paraná, Programa de Pós-Graduação em Contabilidade

Av. Prefeito Lothário Meissner, no 632, Jardim Botânico, 80210-170, Curitiba, PR, Brazil.

E-mail address: cryssviana1@gmail.com

(1) https://orcid.org/0000-0003-0375-4310

\section{Luiz Panhoca}

Universidade Federal do Paraná, Programa de Pós-Graduação em Contabilidade

Av. Prefeito Lothário Meissner, no 632, Jardim Botânico, 80210-170, Curitiba, PR, Brazil.

E-mail address: panhoca.luiz@gmail.com

(1) https://orcid.org/0000-0002-0839-1611

* Corresponding Author

\section{Funding}

The authors would like to thank the Coordination for the Improvement of Higher Education Personnel (CAPES) for the financial support granted.

\section{Plagiarism Check}

The RAC maintains the practice of submitting all documents approved for publication to the plagiarism check, using specific tools, e.g.: iThenticate.

\section{Copyrights}

RAC owns the copyright to this content.
Vitell, S. J. (2015). A case for consumer social responsibility (CnSR): Including a selected review of consumer ethics/social responsibility research. Journal of Business Ethics, 130(4), 767-774. http://doi.org/10.1007/s10551-014-2110-2

Yu, T. Y., Yu, T. K., \& Chao, C. M. (2017). Understanding Taiwanese undergraduate students' pro-environmental behavioral intention towards green products in the fight against climate change. Journal of Cleaner Production, 161(10), 390-402. https://doi.org/10.1016/j.jclepro.2017.05.115

White, K., MacDonnell, R., \& Ellard, J. H. (2012). Belief in a just world: Consumer intentions and behaviors toward ethical products. Journal of Marketing, 76(1), 103-118. https://doi.org/10.2307/41406841

\section{Authors' Contributions}

$1^{\text {st }}$ author: conceptualization (equal); formal analysis (equal); investigation (equal); methodology (equal); validation (equal); visualization (equal); writing-original draft (equal); writing-review $\&$ editing (equal).

$2^{\text {nd }}$ author: methodology (supporting); resources (supporting); data curation (supporting); acquisition of financing (supporting).

$3^{\text {rd }}$ author: formal analysis (equal); investigation (equal); methodology (equal); supervision (equal); validation (equal); writing-original draft (equal); writing-review \& editing (lead).

\section{Conflict of Interests}

The authors have stated that there is no conflict of interest.

\section{Peer Review Method}

This content was evaluated using the double-blind peer review process. The disclosure of the reviewers' information on the first page, as well as the Peer Review Report, is made only after concluding the evaluation process, and with the voluntary consent of the respective reviewers and authors.

\section{Data Availability}

All data and materials were made publicly available through the Harvard Dataverse platform and can be accessed at:

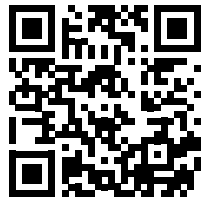

Alison Martins Meurer; Cristina Viana de Jesus; Luiz Panhoca, 2020, "Replication Datafor:Environmental Responsibility, Psychological Distance, and Environmental Consumption: Mediation in Accounting Students", Harvard Dataverse, V1. https://doi.org/10.7910/DVN/6WCMHF

RAC encourages data sharing but, in compliance with ethical principles, it does not demand the disclosure of any means of identifying research subjects, preserving the privacy of research subjects. The practice of open data is to enable the reproducibility of results, and to ensure the unrestricted transparency of the results of the published research, without requiring the identity of research subjects.

RAC is a member of, and subscribes to the principles of the Committee on Publication Ethics (COPE) for scholarly publication 


\section{ANNEX I}

Table 1A. Block $1-$ Consumer behavior in relation to pro-environmental products.

\begin{tabular}{|c|c|}
\hline \multirow{4}{*}{ Psychological distance } & 1 - Climate change is likely to have a big impact on people. \\
\hline & 2 - I am sure that climate change is really happening. \\
\hline & 3 - If it happens, Brazil will feel the effects of climate change. \\
\hline & 4- Climate change will affect areas that are close to Brazil. \\
\hline \multirow{5}{*}{ Social responsibility } & 5- I recommend green and/or organic products to my friends and family. \\
\hline & 6-I feel morally obliged to buy green and/or organic products. \\
\hline & 7 - I participate in activities that aim at protecting and improving the quality of the environment. \\
\hline & $\begin{array}{l}8 \text { - I support non-governmental organizations that work to minimize the negative impacts caused by other } \\
\text { organizations to the environment. }\end{array}$ \\
\hline & 9 - We must take responsibility for environmental issues. \\
\hline \multirow{5}{*}{ Ethical behavior } & 10 - I avoid buying products that are potentially harmful to the environment. \\
\hline & 11 - When I use ecological and/or organic products, I feel that I can help the environment. \\
\hline & 12 - I feel more comfortable when I use ecological products instead of non-ecological products. \\
\hline & 13 - I try to buy products made with recycled materials. \\
\hline & 14 - To maintain a healthy economy, all living beings have a moral right to exist. \\
\hline \multirow{4}{*}{$\begin{array}{l}\text { Environmental self- } \\
\text { responsibility }\end{array}$} & 15 - I consider environmental issues when making a purchase. \\
\hline & 16 - I have already changed the option to purchase an important product for ecological reasons. \\
\hline & 17 - I think that individuals have a responsibility to protect the environment. \\
\hline & 18 - When I use ecological products, I feel that I support environmental preservation. \\
\hline \multirow{5}{*}{ Purchase intention } & 19 - In the near future, I am willing to buy environmentally friendly products. \\
\hline & 20 - In the near future, I am willing to buy products with an ecological brand. \\
\hline & 21 - In the near future, I plan to buy only products with an ecological brand. \\
\hline & 22 - In the near future, I will only buy products that avoid the use of corrosive chemical materials. \\
\hline & 23 - In the near future, I will buy products made from recyclable materials. \\
\hline \multirow{5}{*}{ Consumer loyalty } & 24 - I will definitely continue to consume environmentally friendly and recyclable products. \\
\hline & 25 - I am willing to pay more money for ecological products. \\
\hline & 26 - Ecological products are always my first choice. \\
\hline & 27 — I consider myself loyal to ecological products. \\
\hline & 28 - If ecological products are not available in the store, I do not buy other products. \\
\hline
\end{tabular}

Note. Source: adapted from Yu et al. (2017). 